\title{
GROWTH RESPONSES, PIGMENT AND STOMATAL BEHAVIOUR OF MAIZE TO FOLIAR APPLICATION OF NAA
}

\author{
NARGIS JAHAN* AND NILUFAR YASMIN \\ Plant Physiology Laboratory, Department of Botany, University of Dhaka, Dhaka-1000, \\ Bangladesh
}

\begin{abstract}
An investigation was conducted to find out the responses of two varieties of maize BHM- 7 $\left(\mathrm{V}_{1}\right)$ and BHM-9 $\left(\mathrm{V}_{2}\right)$ to Naphthalene acetic acid (NAA) on the growth, dry matter, pigment and stomatal behaviour. In case of $\mathrm{V}_{1}$, plant height was found to decrease due to all the treatments at all the ages except at 7 DAS due to $T_{3}$ treatment. In $V_{2}$, increase in plant height was recorded following $T_{1}$ and $T_{3}$ treatments at all the ages except at 21 DAS. In both the varieties at all the ages, maximum number of leaves per plant were obtained from $T_{3}$ treatment. In case of $V_{1}$ number of leaves per plant increased only due to $T_{3}$ treatment in comparison to control whereas, in $V_{2}$ number of leaves per plant increased following all the treatments. In case of $\mathrm{V}_{1}$, dry weight of shoot increased due to $T_{3}$ treatment at 8 and 15 DAS. But in case of $V_{2}$, there was increasing tendency in dry weight of shoot due to all treatments at all ages except at 8 DAS due to $T_{2}$ treatment. In both the varieties dry weight of root increased due to $T_{3}$ treatment at all ages. Chl. a was more than chl. $b$ at all the stages in both the varieties and both chl. a and chl. $\mathrm{b}$ were recorded lowest at the flowering stage. In case of $\mathrm{V}_{1}$, amount of chl. $\mathrm{b}$ was remarkably higher at the tillering stage whereas, in case of $\mathrm{V}_{2}$, amount of chl. a and carotenoid were remarkably higher at the grain filling stage. In both the varieties, the amount of chl. a was found to increase and decrease due to all the treatments at all the stages. Chlorophyll b both increased and decreased in $\mathrm{V}_{1}$ and the maximum increase was due to $\mathrm{T}_{3}$ at the tillering and grain filling stages. In case of $\mathrm{V}_{2}$, chl. b increased at the tillering stage following all the treatments and maximum increase was also due to $\mathrm{T}_{3}$. However, in $\mathrm{V}_{1}$ carotenoid contents of leaf increased following all the treatments at the tillering stage and decreased following all the treatments at flowering and grain filling stages. Number of stomata increased except due to $T_{2}$ in $V_{1}$, whereas, number of epidermal cell decreased due to $T_{0}$ and $T_{2}$ in $V_{1}$. Stomatal density in $V_{2}$ was found relatively higher due to NAA application. It was also found that NAA increased the stomatal density with the increase of concentration except $50 \mathrm{ppm}\left(\mathrm{T}_{2}\right)$ in $\mathrm{V}_{2}$. Stomatal index was found to decrease due to $\mathrm{T}_{1}$ inV $\mathrm{V}_{1}$ and due to $\mathrm{T}_{0}$ in $\mathrm{V}_{2}$.
\end{abstract}

Key words: Maize, Growth, Pigment, Stomatal behaviour, Foliar application, NAA

\section{INTRODUCTION}

Maize (Zea mays L.) is an important cereal crop ranking third after rice and wheat in the world and also in Bangladesh (Haque 2003). It is one of the most important crops

\footnotetext{
* Corresponding author: <jahan.nargis@yahoo.com>.
} 
both for human and animal consumption. In acreage it is next to wheat and in productivity it is next to rice. It has been proved as a profitable grain because of its high productivity and low production cost. With the changing climate and rainfall patterns crop yields in Bangladesh are projected to decline. There is almost no scope for bringing new land under cultivation. In 2014 - 15 the total maize production was approximately 7.0 metric tons per hectare (BBS 2015). This yield level is poor in comparison to that of other countries. The demand of maize is also increasing day by day in Bangladesh. So its production per unit area should be increased.

There are quite a number of methods which may help to increase the crop production. The use of growth regulators is considered as one of the ways for such an attempt. In many countries of the world, experiments have been carried out to investigate effects of NAA, a synthetic auxin on the yield and quality of cereal crops including maize (Chaudhury et al. 1980, Sing and Gill 1985, Grewal and Gill 1986, Muthukumar et al. 2005). But, in Bangladesh very limited research has been done on growth and yield aspects on cereal crops with NAA viz. rice (Adam and Jahan 2011), wheat (Jahan and Adam 2013, Islam and Jahan 2016 ) and only a preliminary work was reported regarding the effect of NAA on maize (Akter 2010).

Stomatal mechanism encapsulates much of plant physiology - this is valid for the perception of irradiance, some photosynthetic reactions, membrane transport, cell water reactions and many other processes. Effects of growth regulator on the stomatal behaviour particularly stomatal density and stomatal index were not studied in detail. Only one report is available regarding the effect of NAA on the number of stomata of maize (Akter 2010).

Therefore, the present investigation was undertaken to study the effect of NAA on growth, dry matter, pigment and stomatal behaviour of two varieties of maize.

\section{MATERIALS AND METHODS}

The experiment was conducted in the experimental plot of the Department of Botany, University of Dhaka from April to June 2014 with two hybrid varieties of maize, BHM- 7 and BHM-9. Fertilizers were applied at the rate of 500, 210, 260 and $200 \mathrm{~kg}$ per hectare of urea, gypsum, triple super phosphate and muriate of potash respectively (Fertilizer Recommendation Guide 2012) as basal dose during land preparation. The experiment was laid out in a randomized complete block design (RCBD) with four replications. Seeds collected from BARI, Joydebpur, Gazipur were sterilized with $0.5 \%$ $\mathrm{Ca}(\mathrm{OCl})_{2}$ solution for five minutes and repeatedly washed in distilled water to remove any trace of $\mathrm{Ca}(\mathrm{OCl})_{2}$. Seeds were sown on April 2, 2014 directly in rows. Row to row distances were $20 \mathrm{~cm}$. Thinning was done at the age of 10 days after emergence (DAE) of 
the seedlings in such a way that healthy seedlings of uniform size and vigor were allowed to grow. In each row, the distance from one seedling to another was $20 \mathrm{~cm}$. Watering was done as per necessity. Weeding was done at the age of 30 DAE. There were four treatments as follows- $\mathrm{T}_{0}=$ distilled water (control), $\mathrm{T}_{1}=25 \mathrm{ppm}$ NAA, $\mathrm{T}_{2}=50 \mathrm{ppm}$ NAA and $T_{3}=75$ ppm NAA. Treatments were applied as foliar spray at 32 DAE. Data on plant height and number of branches per plant were recorded at an interval of one week starting from 7 days after spray (DAS) up to 42 DAS. Dry weight of shoot and root were recorded from the age of 1 DAS at an interval of one week up to 15 DAS. Leaf pigments were determined at three stages viz. tillering, flowering and grain filling stages. Chlorophyll a and b contents were determined following Mckinney (1940) and Machlachalan and Zalik (1963). The amount of carotenoids was determined by the equation of von Wettstein (1957). Stomatal density and stomatal index were determined from the abaxial surface of the leaves. Number of stomata and epidermal cells were counted from temporary mounts of epidermal peels by a precalibrated microscope. Density of stomata was determined as the total number of stomata per unit area and was expressed per $\mathrm{mm}^{2}$ and stomatal index was calculated from the formula of Pandeya et al. (1968). Data were analyzed statistically (Steel and Torrie 1960) and treatment means were compared by LSD test at $5 \%$ level of significance.

\section{RESULTS AND DISCUSSION}

Marked variation on the growth was noted between the varieties. Plants of BHM- 7 $\left(\mathrm{V}_{1}\right)$ showed vigorous vegetative growth (Table 1 ) and the number of leaves were more (Table 2). The results presented in Table 1 showed that significant variations in plant height were observed only at 14 DAS in $V_{2}$. In case of $V_{1}$, plant height was found to decrease due to all the treatments at all the ages except at 7 DAS due to $T_{3}$ treatment.

Table 1. Effect of NAA on plant height $(\mathrm{cm})$ of two varieties of maize at different days after spray (DAS).

\begin{tabular}{|c|c|c|c|c|c|c|c|c|c|c|}
\hline \multirow{3}{*}{ Treatments } & \multicolumn{10}{|c|}{ Age of plants in days after spray (DAS) } \\
\hline & \multicolumn{5}{|c|}{ MHM-7 $\left(\mathrm{V}_{1}\right)$} & \multicolumn{5}{|c|}{ MHM-9 $\left(\mathrm{V}_{2}\right)$} \\
\hline & 7 & 14 & 21 & 35 & 42 & 7 & 14 & 21 & 35 & 42 \\
\hline $\mathrm{T}_{0}$ & 78.58 & 96.12 & 152.78 & 175.24 & 178.79 & 73.79 & $84.81 \mathrm{~b}$ & 142.84 & 154.46 & 159.40 \\
\hline $\mathrm{T}_{1}$ & 74.97 & 81.07 & 150.67 & 173.78 & 175.51 & 75.69 & $86.46 \mathrm{~b}$ & 139.11 & 155.95 & 161.39 \\
\hline $\mathrm{T}_{2}$ & 71.55 & 82.98 & 151.14 & 174.86 & 175.24 & 64.30 & $79.70 \mathrm{~b}$ & 126.40 & 147.78 & 153.50 \\
\hline $\mathrm{T}_{3}$ & 83.71 & 91.79 & 146.86 & 172.21 & 173.90 & 79.08 & $100.65 \mathrm{a}$ & 139.67 & 156.53 & 167.70 \\
\hline $\mathrm{CV}(\%)$ & 22.21 & 21.49 & 20.21 & 19.72 & 20.17 & 13.52 & 16.22 & 12.81 & 15.60 & 11.87 \\
\hline $\operatorname{LSD}(0.05)$ & NS & NS & NS & NS & NS & NS & 12.87 & NS & NS & NS \\
\hline
\end{tabular}


In $\mathrm{V}_{2}$, plant height decreased due to all the treatments only at 21 DAS, whereas, decreased at all the ages due to $\mathrm{T}_{2}$ treatment. However, increase in plant height was recorded following $T_{1}$ and $T_{3}$ treatments at all other ages. Tallest plants were recorded following $\mathrm{T}_{3}$ and was significant only at 14 DAS. Akter (2010) reported both increase and decrease in plant height of maize following NAA application. Similar results of increases and decreases in plant height due to NAA application were also reported in rice (Adam and Jahan 2011) and in wheat (Jahan and Adam 2013).

Table 2 showed that number of leaves per plant were significantly influenced at 35 and 42 DAS in $V_{1}$ and only at 35 DAS in $V_{2}$. Maximum number of leaves per plant of both the varieties were obtained from $T_{3}$ treatment at all the ages. In case of $V_{1}$ at all the ages number of leaves per plant increased only due to $T_{3}$ treatment and also due to $T_{2}$ at 14 DAS. However, in $V_{2}$ number of leaves per plant increased following all the treatments. The positive effect of NAA in the number of leaves per plant in rice (Chaudhury et al. 1980) and in wheat and barley (Harshan and Gill 1985) has been previously reported. Number of leaves per plant were found to increase and decrease following NAA application in different plants by different workers (Harshan and Gill 1985, Adam and Jahan 2011, Islam and Jahan 2016).

Table 2. Effect of NAA on number of leaves per plant of two varieties of maize at different days after spray (DAS).

\begin{tabular}{|c|c|c|c|c|c|c|c|c|c|c|}
\hline \multirow{3}{*}{ Treatments } & \multicolumn{10}{|c|}{ Age of plants in days after spray (DAS) } \\
\hline & \multicolumn{5}{|c|}{ MHM-7 $\left(\mathrm{V}_{1}\right)$} & \multicolumn{5}{|c|}{ MHM-9 $\left(\mathrm{V}_{2}\right)$} \\
\hline & 7 & 14 & 21 & 35 & 42 & 7 & 14 & 21 & 35 & 42 \\
\hline $\mathrm{T}_{0}$ & 10.58 & 11.58 & 13.33 & $15.50 \mathrm{a}$ & $16.17 \mathrm{~b}$ & 9.21 & 10.25 & 11.58 & $12.67 \mathrm{~b}$ & 14.00 \\
\hline $\mathrm{T}_{1}$ & 10.00 & 10.83 & 13.17 & $15.33 \mathrm{a}$ & $16.00 \mathrm{~b}$ & 9.91 & 10.34 & 11.99 & $13.00 \mathrm{~b}$ & 14.58 \\
\hline $\mathrm{T}_{2}$ & 9.83 & 11.75 & 13.00 & $14.33 \mathrm{~b}$ & $15.25 \mathrm{c}$ & 9.99 & 10.67 & 12.25 & $13.67 \mathrm{a}$ & 14.67 \\
\hline $\mathrm{T}_{3}$ & 10.83 & 11.92 & 13.67 & $15.67 \mathrm{a}$ & $16.84 \mathrm{a}$ & 10.50 & 11.00 & 12.84 & $14.00 \mathrm{a}$ & 14.75 \\
\hline $\mathrm{CV}(\%)$ & 8.24 & 7.92 & 7.63 & 17.16 & 18.39 & 18.39 & 6.91 & 6.23 & 7.24 & 12.11 \\
\hline LSD (0.05) & NS & NS & NS & 0.684 & 0.311 & NS & NS & NS & 0.785 & NS \\
\hline
\end{tabular}

Significant influence on dry weight of shoot was observed only at 15 DAS in $V_{1}$ (Table 3). Dry weight of shoot was found to increase and decrease in both the varieties due to different NAA treatments. In case of $\mathrm{V}_{1}$, dry weight of shoot decreased at all ages due to $T_{1}$ and $T_{2}$ treatments and also at 1 DAS due to $T_{3}$. The two increases were due to $\mathrm{T}_{3}$ treatments at $8 \mathrm{DAS}$ and $15 \mathrm{DAS}$. But in case of $\mathrm{V}_{2}$, there was increasing tendency in dry weight of shoot due to all treatments at all ages except at 8 DAS due to $\mathrm{T}_{2}$ treatment. Significant increase in dry weight of shoot of maize at harvest was also reported due to different NAA treatments (Akter 2010). Increased dry weight of other cereal plants due to 
NAA application has also been reported by different investigators on different plants viz. rice (Jahan and Adam 2011) and wheat (Jahan and Adam 2013). Both increase and decrease in dry matter of various other plants following NAA application were also reported by several workers viz. Karim and Fattah (2007) on chickpea and Ullah et al. (2007) on cowpea.

Table 3. Effect of NAA on dry weight of shoot (g) of two varieties of maize at different days after spray (DAS).

\begin{tabular}{|c|c|c|c|c|c|c|}
\hline \multirow{3}{*}{ Treatments } & \multicolumn{6}{|c|}{ Age of plants in days after spray (DAS) } \\
\hline & \multicolumn{3}{|c|}{ BHM-7 $\left(\mathrm{V}_{1}\right)$} & \multicolumn{3}{|c|}{ BHN-9 $\left(\mathrm{V}_{2}\right)$} \\
\hline & 1 & 8 & 15 & 1 & 8 & 15 \\
\hline $\mathrm{T}_{0}$ & 14.842 & 16.534 & $26.477 \mathrm{a}$ & 16.065 & 21.047 & 30.628 \\
\hline $\mathrm{T}_{1}$ & 11.931 & 13.169 & $19.898 \mathrm{~b}$ & 16.742 & 23.129 & 31.463 \\
\hline $\mathrm{T}_{2}$ & 10.466 & 12.848 & $21.514 \mathrm{~b}$ & 17.566 & 18.251 & 30.839 \\
\hline $\mathrm{T}_{3}$ & 13.267 & 17.228 & $26.682 \mathrm{a}$ & 19.435 & 22.400 & 32.525 \\
\hline $\mathrm{CV}(\%)$ & 18.60 & 18.66 & 15.34 & 16.20 & 19.29 & 3.46 \\
\hline LSD (0.05) & NS & NS & 4.94 & NS & NS & NS \\
\hline
\end{tabular}

Table 4. Effect of NAA on dry weight of root (g) of two varieties of maize at different days after spray (DAS).

\begin{tabular}{|c|c|c|c|c|c|c|}
\hline \multirow{3}{*}{ Treatments } & \multicolumn{6}{|c|}{ Age of plants in days after spray (DAS) } \\
\hline & \multicolumn{3}{|c|}{ BHM-7 $\left(\mathrm{V}_{1}\right)$} & \multicolumn{3}{|c|}{ BHN-9 $\left(\mathrm{V}_{2}\right)$} \\
\hline & 1 & 8 & 15 & 1 & 8 & 15 \\
\hline $\mathrm{T}_{0}$ & 0.981 & $2.463 \mathrm{~b}$ & 3.506 & $1.730 \mathrm{~b}$ & $2.218 \mathrm{~b}$ & $3.427 \mathrm{c}$ \\
\hline $\mathrm{T}_{1}$ & 0.927 & $3.538 \mathrm{a}$ & 3.618 & $1.599 \mathrm{c}$ & $2.366 \mathrm{a}$ & $3.794 \mathrm{~b}$ \\
\hline $\mathrm{T}_{2}$ & 0.836 & $2.009 \mathrm{~b}$ & 2.943 & $1.936 \mathrm{a}$ & $2.044 \mathrm{c}$ & $3.891 \mathrm{~b}$ \\
\hline $\mathrm{T}_{3}$ & 1.014 & $2.572 \mathrm{~b}$ & 3.841 & $1.747 \mathrm{~b}$ & $2.395 \mathrm{a}$ & $4.102 \mathrm{a}$ \\
\hline $\mathrm{CV}(\%)$ & 11.48 & 24.46 & 9.96 & 7.84 & 6.47 & 6.92 \\
\hline LSD (0.05) & NS & 0.602 & NS & 0.126 & 0.044 & 0.134 \\
\hline
\end{tabular}

Dry weight of root of $V_{1}$ was decreased due to $T_{2}$ treatment but increased due to $T_{3}$ treatment at all ages (Table 4). In case of $\mathrm{V}_{2}$, dry weight of root was increased following all the NAA treatments at all the ages except at 1 DAS due to $T_{1}$ and 8 DAS due to $T_{2}$ treatment. Similar results of increase and decrease in dry weight of root following NAA application have also been reported in other plants (Al-Wahaibi et al. 2012). Dry matter of any crop is the output of net photosynthesis. It is mostly depended on the size of the photosynthetic system or its activity as well as the length of the growth period during which photosynthesis continues. In both the varieties, at 15 DAS dry weight of root was 
highest due to $\mathrm{T}_{3}$ and this provides a clear evidence of a shift of allocation in growth resources in favour of root development.

Table 5. Effect of NAA on pigment content of leaf $(\mathrm{mg} / \mathrm{g})$ of BHM-7 $\left(\mathrm{V}_{1}\right)$ at three different stages.

\begin{tabular}{|c|c|c|c|c|c|c|c|c|c|}
\hline \multirow[t]{2}{*}{ Treatments } & \multicolumn{3}{|c|}{ Tillering } & \multicolumn{3}{|c|}{ Flowering } & \multicolumn{3}{|c|}{ Grain filling } \\
\hline & Chl.a & Chl.b & Carotenoids & Chl.a & Chl.b & Carotenoids & Chl.a & Chl.b & Carotenoids \\
\hline $\mathrm{T}_{0}$ & $0.736 \mathrm{~b}$ & 0.473 & 6.113 & $0.530 \mathrm{a}$ & 0.182 & $4.826 \mathrm{a}$ & 0.822 & 0.271 & 5.622 \\
\hline $\mathrm{T}_{1}$ & $0.729 b$ & 0.401 & 6.400 & $0.515 \mathrm{a}$ & 0.241 & $4.437 \mathrm{a}$ & 0.535 & 0.301 & 5.995 \\
\hline$T_{2}$ & $1.035 \mathrm{a}$ & 0.528 & 6.142 & $0.171 \mathrm{~b}$ & 0.151 & $3.199 \mathrm{~b}$ & 0.756 & 0.235 & 6.519 \\
\hline $\mathrm{T}_{3}$ & $0.675 \mathrm{~b}$ & 0.554 & 6.162 & $0.583 \mathrm{a}$ & 0.221 & $4.983 \mathrm{a}$ & 0.657 & 0.318 & 5.541 \\
\hline $\mathrm{CV}(\%)$ & 51.90 & 14.67 & 12.04 & 39.15 & 2.62 & 19.86 & 11.84 & 17.02 & 7.02 \\
\hline LSD $(0.05)$ & 0.501 & NS & NS & 0.126 & NS & 0.978 & NS & NS & NS \\
\hline
\end{tabular}

Table 6. Effect of NAA on pigment content of leaf $(\mathrm{mg} / \mathrm{g})$ of BHM-9 $\left(\mathrm{V}_{2}\right)$ at three different stages.

\begin{tabular}{|c|c|c|c|c|c|c|c|c|c|}
\hline \multirow[t]{2}{*}{ Treatments } & \multicolumn{3}{|c|}{ Tillering } & \multicolumn{3}{|c|}{ Flowering } & \multicolumn{3}{|c|}{ Grain filling } \\
\hline & Chl.a & Chl.b & Carotenoids & Chl.a & Chl.b & Carotenoids & Chl.a & Chl.b & Carotenoids \\
\hline $\mathrm{T}_{0}$ & $0.389 \mathrm{~b}$ & 0.180 & $4.278 \mathrm{~b}$ & $0.223 \mathrm{c}$ & $0.146 \mathrm{a}$ & $4.290 \mathrm{a}$ & $0.647 \mathrm{a}$ & $0.245 \mathrm{a}$ & 6.018 \\
\hline $\mathrm{T}_{1}$ & $0.523 \mathrm{a}$ & 0.245 & $5.615 \mathrm{a}$ & $0.415 \mathrm{a}$ & $0.156 \mathrm{a}$ & $3.813 \mathrm{~b}$ & $0.537 \mathrm{c}$ & $0.298 \mathrm{a}$ & 5.832 \\
\hline $\mathrm{T}_{2}$ & $0.312 \mathrm{c}$ & 0.282 & $4.285 \mathrm{~b}$ & $0.273 b$ & $0.077 \mathrm{~b}$ & $2.037 \mathrm{c}$ & $0.516 \mathrm{c}$ & $0.167 \mathrm{~b}$ & 4.897 \\
\hline $\mathrm{T}_{3}$ & $0.360 \mathrm{~b}$ & 0.299 & $3.942 \mathrm{~b}$ & $0.167 \mathrm{~d}$ & $0.080 \mathrm{~b}$ & $1.403 \mathrm{~d}$ & $0.793 \mathrm{a}$ & $0.281 \mathrm{a}$ & 5.177 \\
\hline $\mathrm{CV}(\%)$ & 21.86 & 4.38 & 17.90 & & 36.13 & 43.7 & 18.7 & 21.3 & 11.8 \\
\hline $\operatorname{LSD}(0.05)$ & 0.051 & NS & 1.14 & 0.048 & 0.023 & 0.322 & 0.044 & 0.056 & NS \\
\hline
\end{tabular}

Results revealed that chl. a was more than chl. $b$ at all the stages in both the varieties. In case of $\mathrm{V}_{1}$ chlorophyll a varied significantly at tillering and flowering stages (Table 5) but, in $V_{2}$ it was significantly influenced by different treatments at all the three stages (Table 6). In both the varieties, the amount of chl. a was found to increase and decrease due to different treatments at all the stages. In $\mathrm{V}_{2}$, amount of chl.a was found highest due to all the treatments at the grain filling stage. Chlorophyll $b$ was not significantly influenced at any stage in $\mathrm{V}_{1}$ (Table 5), but in $\mathrm{V}_{2}$ it was significantly influenced at the flowering and grain filling stages (Table 6). Highest amount of chl. $\mathrm{b}$ in $\mathrm{V}_{1}$ was obtained at the tillering stage while in $\mathrm{V}_{2}$ chl. $\mathrm{b}$ was highest at the grain filling stage. Chlorophyll $\mathrm{b}$ both increased and decreased in $V_{1}$ and the maximum increase was due to $T_{3}$ at the tillering and grain filling stages. In case of $V_{2}$, chl. $b$ increased at the tillering stage following all the treatments and maximum increase was also due to $T_{3}$. In both the varieties chl. a and chl. $b$ were recorded lowest at the flowering stage. Significant variations in carotenoid contents were observed only at the flowering stage in $V_{1}$ whereas, at the tillering and flowering stages in $\mathrm{V}_{2}$. Carotenoids were remarkably higher 
in the leaves of $\mathrm{V}_{1}$ at all the three stages (Table 5) than those of $\mathrm{V}_{2}$ (Table 6). In case of $V_{1}$ maximum carotenoids was obtained at the tillering stage except due to $T_{2}$ and in $V_{2}$ it was maximum at the grain filling stage. However, in comparison to control carotenoid contents of leaf increased following all the treatments at the tillering stage in $\mathrm{V}_{1}$ and decreased following all the treatments at flowering and grain filling stages in $\mathrm{V}_{2}$. There are a number of reports on the increase in leaf pigments of different kinds of plants following NAA treatments (Chaudhury et al. 1980, Grewal and Gill 1986, Jahan et al. 1992). Jahan and Adam (2014) reported that pigment content of leaf at different stages increase in one variety of rice while decrease in another variety depending on concentration of the chemical. The decrease in pigment content may be due to increase in number of older leaves which lost photosynthetic activity. This is also because pigments breakdown after certain growth stage.

Table 7. Effect of NAA on stomatal density and stomatal index in two varieties of maize.

\begin{tabular}{|c|c|c|c|c|c|c|c|}
\hline \multirow[t]{2}{*}{ Variety } & \multicolumn{2}{|c|}{$\begin{array}{l}\text { No. of stomata and } \\
\text { epidermal cell before } \\
\text { spray }\end{array}$} & \multirow[t]{2}{*}{$\begin{array}{l}\text { Stomatal } \\
\text { Index } \\
\text { (SI) }\end{array}$} & \multirow[t]{2}{*}{ Treatments } & \multicolumn{2}{|c|}{$\begin{array}{l}\text { No. of stomata and } \\
\text { epidermal cell after } \\
\text { spray }\end{array}$} & \multirow[t]{2}{*}{$\begin{array}{l}\text { Stomatal } \\
\text { Index } \\
\text { (SI) }\end{array}$} \\
\hline & Stomata & $\begin{array}{c}\text { Epidermal } \\
\text { cell }\end{array}$ & & & Stomata & $\begin{array}{c}\text { Epidermal } \\
\text { cell }\end{array}$ & \\
\hline & & & & $\mathrm{T}_{0}$ & 55.72 & 286.02 & 0.16 \\
\hline \multirow[t]{4}{*}{$\mathrm{V}_{1}$} & 53.5 & 360 & 0.13 & $\mathrm{~T}_{1}$ & 57.71 & 420.01 & 0.12 \\
\hline & & & & $\mathrm{T}_{2}$ & 49.03 & 318.0 & 0.13 \\
\hline & & & & $\mathrm{T}_{3}$ & 57.87 & 364.60 & 0.14 \\
\hline & & & & $\mathrm{T}_{0}$ & 56.47 & 461.32 & 0.11 \\
\hline \multirow[t]{3}{*}{$\mathrm{V}_{2}$} & 52.5 & 350 & 0.13 & $\mathrm{~T}_{1}$ & 72.55 & 456.97 & 0.14 \\
\hline & & & & $\mathrm{T}_{2}$ & 78.18 & 428.64 & 0.16 \\
\hline & & & & $\mathrm{T}_{3}$ & 82.93 & 468.16 & 0.16 \\
\hline
\end{tabular}

The results given in Table 7 showed that before spray, number of stomata on the dorsal surfaces in $\mathrm{V}_{1}$ and $\mathrm{V}_{2}$ were 53.5 and 52.5 per $\mathrm{mm}^{2}$, respectively. But after spray, the number of stomata increased except due to $T_{2}$ in $V_{1}$, whereas, number of epidermal cell decreased due to $T_{0}$ and $T_{2}$ in $V_{1}$. Stomatal density in $V_{2}$ was found relatively higher due to NAA application. It was also found that NAA increased the stomatal density with the increase of concentration except $50 \mathrm{ppm}\left(\mathrm{T}_{2}\right)$ in $\mathrm{V}_{2}$. Stomatal index was found to decrease due to $T_{1}$ in $V_{1}$ and due to $T_{0}$ in $V_{2}$. Akter (2010) reported significant decrease in number of stomata in maize var. Pacific 283 with an increase in concentration of NAA. The decrease in number of stomata indicates that the loss of water through transpiration decreased. Hence, less amount of water is required for this crop. It also reduces the irrigation and labour cost. It is a positive indication for better adaptation in dry region. As maize is a $\mathrm{C} 4$ plant, its productivity will also be increased. All these indicate that 
stomatal density and index have some influence on plant growth. However, stomatal study in relation to growth regulator warrant further study.

Thus the results obtained during this experiment indicated that NAA has effect on different physiological and biochemical parameters, but the magnitude of the effect depended on concentrations of NAA and also on the parameters observed. Of all the concentratios of NAA, $75 \mathrm{ppm}\left(\mathrm{T}_{3}\right)$ produced better stimulation. Moreover, two varieties of maize responded differently.

\section{REFERENCES}

Adam, A. M. M. G. and N. Jahan. 2011. Effects of naphthalene acetic acid on yield attributes and yield of two varieties of rice (Oryza sativa L.) Bangladesh J. Bot. 40(1): 97-100.

Akter, R. 2010. Effect of Naphthalene acetic acid (NAA) on growth, physiological and biochemical responses and yield attributes of maize (Zea mays L. var. Pacific 283). MS Thesis. Department of Botany, University of Dhaka.

Al-Whaibi, M. H., M. H. Siddiqui, B. M. A. Al-Munqadhi, A. M. Sakran, H. M. Ali and M. O. Basalah. 2012. Influence of plant growth regulators on growth performance and photosynthetic pigments status of Eruca sativa Mill. J. Med. Plants Res. 6: 1948-1954.

BBS. Statistical Year Book of Bangladesh. 2015. Bangladesh Bureau of Statistics Planning Division, Ministry of Planning, Government of the People's Republic of Bangladesh.

Chaudhuri, D., P. Basuchaudhuri and D. K. D. Gupta. 1980. Effect of growth substances on growth and yield of rice. Indian Agriculturist. 24: 169- 75.

Fertilizer Recommendation Guide 2012. Bangladesh agricultural Research Council. Farmgate, Dhaka-1215. p. 274.

Grewal, H. S. and H. S. Gill. 1986. Influence of NAA and nitrogen on the growth and yield of late planted paddy (Oryza sativa L.). J. Agril. Sci. 106: 37- 40.

Haque, M. M. 2003. Variety development in maize and its characteristics in Bangladesh. Published by BARI, CYMMIT and Integrated maize development project, Bangladesh. pp.17-22.

Harsharn, S. and S. H. Gill. 1985. Effect of foliar spray of NAA on the growth and yield of late sown wheat and barley. Indian J. Ecol. 20(2): 15-21.

Islam, S. and N. Jahan. 2016. Growth and yield responses of Triticum aestivum L. var. BARI gom26 following application of Naphthalene acetic acid at varying nitrogen levels. Bangladesh J. Bot. 45(2): 411-418.

Jahan, N. and A. M. M. G. Adam. 2011. Comparative growth analysis of two varieties of rice following naphthalene acetic acid application. Bangladesh J. Acad. Sci. 35(1):113-120.

Jahan, N. and A. M. M. G. Adam. 2013. Growth and yield responses of BARI gom-26 (Triticum aestivum L.) to Naphthalene acetic acid. Dhaka Univ. J. Biol. Sci. 22(2): 119-125.

Jahan, N. and A. M. M. G. Adam. 2014. Changes in biochemical components of rice folowing NAA application. J. Asiat. Soc. Bangladesh, Sci. 40(2): 173-178.

Jahan, N., Q. A. Fattah and M. K. Roy. 1992. Effect of NAA and IBA on some biochemical compound of bitter gourd. Bangladesh J. Sci. Res. 10(1): 37-11.

Karim, M. F. and Q. A. Fattah. 2007. Growth analysis of chickpea cv. BARI chola-6 as affected by foliar spray of growth regulators. Bangladesh J. Bot. 36(2): 105-110. 
Maclachalan, S. and S. Zalik. 1963. Plastid structure, chlorophyll concentration and free amino acid composition of a chlorophyll mutant of barley. Can. J. Bot. 41: 1053-1062.

Mckinney, G. 1940. Criteria for purity of chlorophyll preparations. J. Biol. Chem. 132: 91-107.

Muthukumar, V. B., K. Velayudham and N. Thavaprakaash. 2005. Growth and yield of baby corn (Zea mays L.) as influenced by PGRs and different time of Nitrogen application. Res. J. Agric. Biol. Sci. 1(4): 303-307.

Pandeya, S. C., G. S. Puri and J. S. Sing. 1968. Research Methods in Plant Ecology. Asia Publishing House, Bombay. pp. 272.

Singh, H. and H. S. Gill. 1985. Effect of foliar spray of NAA on the growth and yield of late sown wheat and barley. Indian J. Eco. 12: 267-272.

Steel, R. G. D. and J. H. Torrie. 1960. Principles and Procedures of statistics. McGraw- Hill, New York. pp. 481.

Ullah, M. J., Q. A. Fattah and F. Hossain. 2007. Response of growth, yield attributes and yield to the application of KNap and NAA in cowpea (Vigna unguiculata (L.) Walp). Bangladesh J. Bot. 36(2): 127- 132.

Von-Wettstein, D. 1957. Chlorophyll-lethal under Submikroskopisoche Formechse der Plastiden. Expt. Cell Res. 12: 427-507.

(Received revised manuscript on 31 January, 2017) 